\title{
Х.Ф. Кехіопуло
}

\section{ПОКАЗНИКИ СИСТЕМ КОАГУЛЯЦІЇ ТА ФІБРИНОЛІЗУ, МАРКЕРИ ЗАПАЛЕННЯ У ХВОРИХ НА ЦУКРОВИЙ ДІАБЕТ 2-ГО ТИПУ 3 ОЖИРІННЯМ}

\author{
Український науково-практичний центр ендокринної хірургії, \\ трансплантації ендокринних органів і тканин МОЗ України, Київ
}

\section{ВСТУП}

Згідно із сучасними уявленнями, цукровий діабет (ЦД) 2-го типу та вісцеральне ожиріння характеризуються станом хронічного підгострого системного запалення, а також протромбогенними змінами гемостазу та фібринолізу, що значно збільшує ризик виникнення серцево-судинних захворювань (СС3) [1]. Серед протромбогенних змін найбільш вивченим є поєднання вісцерального ожиріння зі збільшенням концентрації інгібітору активатора плазміногену 1-го типу (ІАП-1) [2]. Вивчення асоціації показників гемостазу з класичними метаболічними чинниками ризику розвитку ЦД 2-го типу та вісцерального ожиріння допомагає ліпше зрозуміти патогенез ССЗ [3]. Хоча підвищення рівня IAП-1 не єдиний механізм, що призводить до протромбогенного стану на тлі ожиріння, даних літератури щодо взаємозв'язку інших чинників і ланок гемостазу з ЦД 2-го типу та вісцеральним ожирінням бракує.

Надто актуальною є проблема вісцерального ожиріння у хворих на ЦД 2-го типу. Ризик розвитку ССЗ у таких пацієнтів значно зростає, що обумовлює важливість раннього виявлення та корекції патологічних змін. Основою терапії, спрямованої на запобігання прогресуванню ЦД 2-го типу й розвитку ССЗ, є вплив на інсулінорезистентність [4].

Незважаючи на зростання поширеності ЦД 2-го типу, вісцерального ожиріння та СС3, патогенетичні механізми, що лежать в основі прозапального та прокоагулянтного станів за цих патологій, вивчено недостатньо. Крім того, відсутні загальноприйняті підходи до діагностики та лікування запальних і гіперкоагуляційних порушень, що асоціюються із ЦД 2-го типу й ожирінням. Все це свідчить про актуальність проблеми вивчення стану коагуляційної та антикоагуляційної систем, а також значення прозапальних маркерів у цієї категорії хворих. 3 огляду на це мета нашої роботи полягала у вивченні рівня прозапальних маркерів і стану систем коагуляції та фібринолізу у хворих на ЦД 2-го типу 3 вісцеральним ожирінням у взаємозв'язку з чинниками ризику розвитку ССЗ.

\section{МАТЕРІАЛ I МЕТОДИ}

До дослідження було включено 56 пацієнтів, які відповідали таким критеріям: вік від 45 до 65 років; тривалість ЦД 2-го типу від 3 до 10 років; індекс маси тіла (IMT) від 31 до 39 кг/м² у поєднанні з будь-якими двома з наведених ознак: рівень тригліцеридів (ТГ) $\geq 1,7$ ммоль/л; вміст холестерину ліпопротеїнів високої щільності (ХСЛПВЩ) <1,29 ммоль/л; систолічний артеріальний тиск (САТ) $\geq 30$ мм рт. ст. або діастолічний артеріальний тиск (ДАТ) $\geq 85$ мм рт. ст., або антигіпертензивна терапія. Критерії виключення: ЦД 1-го типу; гіпотиреоз; наявність в анамнезі коагулопатій, гострого порушення мозкового кровообігу, інфаркту міокарда, тромбоемболії; замісна гормональна терапія; куріння тютюну. Як контрольну групу обстежено 20 хворих аналогічного віку, з подібною тривалістю ЦД 2-го типу, але без абдомінального ожиріння.

У пацієнтів вивчали скарги, анамнез основного захворювання (ЦД 2-го типу). Фізикальне обстеження включало вимірювання антропометричних параметрів (ріст, маса тіла, окружність талії - ОТ, обчислення IMT), АТ. 3 метою оцінки стану вуглеводного обміну проводили визначення глікемії глюкозооксидазним методом, глікованого гемоглобіну (HbA1c) та імунореактивного інсуліну (IPI) з використанням стандартних наборів реактивів "Рио-Инс-ПГ 125I". Показники ліпідного обміну: вміст загального холестерину - ЗХС, ТГ і ХСЛПВЩ у сироватці крові визначали імуноферментним методом за допомогою діагностичних наборів фірми "Human" (Німеччина) на біохімічному поліаналізаторі "Human" (Німеччина). Рівень ХСЛПНЩ обчислюва- 
ли за формулою Friedwald і співавт. Непрямий показник інсулінорезистентності - індекс НОМАIR (Homeostasis Model Assessment - Insulin Resistance) - розраховували за формулою: глюкоза натще (ммоль/л) × інсулін натще (Од/л) / 22,5.

Для аналізу стану системи гемостазу визначали показники активованого часткового тромбопластинового часу (АЧТЧ), тромбінового часу (ТЧ), рівень фібриногену у плазмі, активність чинника VIII (FVIII) за допомогою наборів реактивів фірми "Human" (Німеччина).

Показники фібринолітичної системи - рівень активності активатора плазміногену тканинного типу (t-PA), антитромбіну III і показника активності антикоагулянтної системи протеїну C, рістоцитин-кофакторну активність чинника Віллебранда (VWF) визначали імуноферментним методом ELISA з використанням наборів реактивів фірми "Technoclone" (Австрія). Як прозапальні маркери досліджували рівні фібриногену і С-реактивного білка (СРБ). Рівень адипонектину визначали за допомогою набору "Biovendor Human Adiponectin ELISA".

Статистичний аналіз отриманих результатів проводили за допомогою програм Microsoft Office Excel 2007 (Microsoft Corp., США) i Portable Statistica 8 (StatSoft, Inc., США). Характер розподілу всіх ознак оцінювали за допомогою критеріїв Шапіро-Уілка та Колмогорова-Смирнова. у зв'язку з тим, що основна маса ознак мала розподіл, який відрізнявся від нормального, результати наведено у вигляді значень медіан та інтерквартильних інтервалів (Me [25; 75]). Враховуючи невеликі розміри вибірок, а також той факт, що більшість аналізованих ознак мали розподіл, відмінний від нормального, для статистичного аналізу отриманих результатів використовували непараметричні статистичні тести. Порівняння двох незалежних груп за безперервними ознаками здійснювали за допомогою U-тесту Манна-Уїтні, а двох залежних груп за допомогою тесту Вілкоксона. Оцінку взає- мозв'язку ознак проводили з використанням методу рангової кореляції Спірмена ( $r$ - коефіцієнт кореляції). Критичний рівень значущості для перевірки статистичних гіпотез приймався за 0,05 .

\section{РЕЗУЛЬТАТИ ТА ОБГОВОРЕННЯ}

Аналіз коагулограм пацієнтів із ЦД 2-го типу та вісцеральним ожирінням виявив найбільш виражені відхилення у показниках АЧТЧ і концентрації фібриногену (табл. 1).

Показник АЧТЧ у хворих на ЦД 2-го типу з ожирінням виявився вірогідно нижчим порівняно 3 таким у контрольній групі $(29,5$ [28,2; 31,9] с проти 32,0 [29,6; 36,2] с, p<0,05). У $9(16,1 \%)$ хворих із ЦД 2-го типу й ожирінням відзначалося вкорочення АЧТЧ менше від 28 с, тоді як в усіх пацієнтів контрольної групи цей показник був у межах референсного інтервалу. Це вкорочення АЧТЧ у групі пацієнтів із ЦД 2-го типу й ожирінням свідчить про наявність у них прокоагулянтного стану та може бути пов'язаним 3 активацією внутрішнього шляху зсідання крові [5]. Крім того, встановлено вірогідну негативну кореляцію АЧТЧ з ОТ (r=-0,34; $p<0,05)$, що відображає посилення тромбофілії на тлі збільшення маси вісцерального жиру в організмі.

Фібриноген є не лише одним із чинників зсідання крові, але також найважливішим маркером запалення [6]. У проведеному дослідженні продемонстровано вірогідне підвищення рівня фібриногену в плазмі крові хворих на ЦД 2-го типу з ожирінням порівняно з показником контрольної групи (3,86 [3,39; 4,58] г/л проти 2,72 $[2,41 ; 3,37]$ г/л, p<0,005). У 25 хворих із ЦД 2-го типу й ожирінням (44,6\%), на відміну від контролю, було виявлено гіперфібриногенемію, що свідчить про наявність хронічного системного запалення та підвищеного серцево-судинного ризику.

Отже, на підставі аналізу коагулограм можна зробити висновок, що виявлення протром-

\section{Таблиця 1}

Показники коагулограми обстежених основної (n=56) і контрольної (n=20) груп

\begin{tabular}{l|c|c|c|c|c}
\hline \multicolumn{1}{c|}{ Показник } & $\begin{array}{c}\text { Основна група } \\
\text { (n=56) }\end{array}$ & $\begin{array}{c}\text { Контрольна група } \\
(\mathbf{n = 2 0 )}\end{array}$ & $\mathbf{U}$ & $\mathbf{p}$ & $\begin{array}{c}\text { Референсний } \\
\text { діапазон }\end{array}$ \\
\hline АЧТЧ, с & $29,5[28,2 ; 31,9]$ & $32,0[29,6 ; 36,2]$ & 327,5 & $<0,05$ & $28,0-40,0$ \\
Протромбіновий індекс (ПТІ), \% & $90,4[84,0 ; 97,0]$ & $90,5[82,0 ; 99,5]$ & 542,0 & $>0,05$ & $70-120$ \\
Тромбіновий час (ТЧ), с & $16,8[16,3 ; 17,2]$ & $17,1[16,3 ; 18,2]$ & 462,0 & $>0,05$ & $14,0-21,0$ \\
Фібриноген, г/л & $3,86[3,39 ; 4,58]$ & $2,72[2,41 ; 3,37]$ & 132,5 & $<0,005$ & $2,0-4,0$ \\
\hline
\end{tabular}


богенних порушень гемостазу вже за результатами таких скринінгових тестів, як визначення АЧТЧ і концентрації фібриногену в плазмі крові, відображає глибину ураження системи гемостазу за ЦД 2-го типу з ожирінням і свідчить про значне підвищення прокоагулянтної активності плазми та збільшення серцево-судинного ризику в обстежених нами пацієнтів. Дані поглибленого дослідження коагуляційної та антикоагуляційної систем крові обстежених наведено у табл. 2.

Активність FVIII у пацієнтів із ЦД 2-го типу й ожирінням склала 74,2 [60,4; 88,5] \%, тобто була вірогідно вищою за таку в контрольній групі ( $<<0,05)$. У 30 пацієнтів $(53,6 \%)$ відзначено підвищення активності FVIII понад верхню межу референсного інтервалу. Підвищення активності FVII у плазмі свідчить про активацію зовнішнього каскаду зсідання крові [7]. Отже, у результаті поглибленого вивчення стану коагуляційної системи у хворих на ЦД 2-го типу з ожирінням у 53,6\% випадків виявлено ознаки активації зовнішнього шляху гемостазу попри те, що скринінгова оцінка цього каскаду (визначення ПТІ) змін не виявила.

Статистично значущого підвищення активностей FVIII і vWF серед хворих із ЦД 2-го типу й ожирінням порівняно з пацієнтами контрольної групи виявлено не було. Натомість відзначено вірогідну позитивну кореляцію активностей FVIII i vWF з антропометричними параметрами та показниками вуглеводного обміну, що може свідчити про підвищення тромбофілії й посилення ендотеліальної дисфункції зі збільшенням вираженості ожиріння, у тому числі вісцерального, та прогресуванням інсулінорезистентності.

Одним із найважливіших інгібіторів фібринолізу є ІАП-1, який інактивує тканинний активатор плазміногену (t-PA) i, отже, запобігає лі- зису фібринових ниток і розчиненню згустку крові. На підтвердження даних літератури нами отримано вірогідне підвищення активності ІАП1 у пацієнтів із ЦД 2-го типу й ожирінням порівняно з контрольною групою хворих (18,6 [10,1; $31,7]$ Од/мл проти 2,8 [1,1; 7,8] Од/мл, p<0,005). Слід зазначити, що підвищення цього показника понад верхню межу референсного діапазону (7 Од/мл) відзначено у 49 із них (87,5\%). Ще у 29 хворих із ЦД 2-го типу й ожирінням $(51,8 \%)$ виявлено рівень активності ІАП-1, який перевищував 20 Од/мл, що свідчить про значне пригнічення фібринолізу та, отже, підвищення ризику розвитку тромбозу.

Активність ІАП-1 у хворих на ЦД 2-го типу й ожиріння була позитивно асоційованою з усіма антропометричними параметрами: масою тіла $(r=0,31 ; p<0,05)$, IMT $(r=0,34 ; p<0,05)$ та ОТ $(r=0,42 ; p<0,05)$, рівнем ТГ $(r=0,36 ; p<0,05)$, концентрацією інсуліну $(r=0,44 ; p<0,001)$ і показником інсулінорезистентності HOMA-IR $(r=0,42 ; p<0,005)$, а також рівнем маркера запалення СРБ ( $r=0,44 ; p<0,005)$. Ці дані свідчать про асоційований розвиток недостатності фібринолізу (а отже, протромбогенного стану) та хронічного запального процесу на тлі прогресування ожиріння та взаємозв'язаних із ним інсулінорезистентноісті та дисліпідемії, що у сукупності призводить до значного підвищення серцево-судинного ризику у цієї категорії хворих.

В обстежених із ЦД 2-го типу й ожирінням виявлено також порушення в антикоагуляційній системі крові. У них відзначно вірогідне підвищення активності антикоагулянту антитромбіну III порівняно з контролем $(97,9$ [86,7; 110,0] \% проти 86, 1 [78,5; 95,3] \%, p<0,05), попри те, що в абсолютній більшості випадків цей параметр був у межах референсного інтервалу. Цей факт можна пояснити як відносну компенсаторну ак-

Таблиця 2

Показники коагуляційної та антикоагуляційної систем крові хворих на цд 2-го типу основної $(n=56)$ і контрольної $(n=20)$ груп

\begin{tabular}{|c|c|c|c|c|c|}
\hline $\begin{array}{l}\text { Показник } \\
\text { активності }\end{array}$ & $\begin{array}{c}\text { Основна група } \\
(n=56)\end{array}$ & $\begin{array}{c}\text { Контрольна група } \\
(n=20)\end{array}$ & $\mathbf{U}$ & $\mathbf{p}$ & $\begin{array}{c}\text { Референсний } \\
\text { діапазон }\end{array}$ \\
\hline FVIII, \% & $74,2[60,4 ; 88,5]$ & $87,9[81,0 ; 116,0]$ & 421,5 & $<0,05$ & $50-150$ \\
\hline VWF, $\%$ & $114,0[98,0 ; 135,0]$ & $98,1[78,2 ; 125,0]$ & 391,0 & $>0,05$ & $50-150$ \\
\hline ІАП-1, Од/мл & $18,6[10,1 ; 31,7]$ & $2,8[1,1 ; 7,8]$ & 174,0 & $<0,005$ & $1-7$ \\
\hline t-РA, Од/мл & $0,09[0,0 ; 0,11]$ & $0,11[0,02 ; 0,19]$ & 531,0 & $>0,05$ & $0,0-0,5$ \\
\hline антитромбіну III, \% & $97,9[86,7 ; 110,0]$ & $86,1[78,5 ; 95,3]$ & 278,0 & $<0,05$ & $80-120$ \\
\hline системи протеїу С & $0,84[0,76 ; 0,98]$ & $0,92[0,84 ; 1,18]$ & 466,5 & $<0,05$ & $0,7-1,3$ \\
\hline
\end{tabular}


тивацію найважливішого антикоагулянту антитромбину III в умовах підвищеного тромбогенного ризику у пацієнтів із ЦД 2-го типу й ожирінням.

Іншим параметром, обраним для дослідження антикоагуляційної системи, була активність системи протеїну С. Активність системи протеїну С у хворих на ЦД 2-го типу з ожирінням становила 0,84 [0,76; 0,98] і виявилася вірогідно нижчою, ніж у контрольній групі $(p<0,05)$; у 13 пацієнтів із ЦД 2-го типу й ожирінням $(23,2 \%)$ виявлено зниження активності цієї системи.

Виявлено слабку, але значущу негативну кореляцію між активністю системи протеїну C i масою тіла $(r=-0,34 ; p<0,05)$ та IMT ( $r=-0,33$; $p<0,05)$, що свідчить про зниження активності цієї антикоагуляційної системи зі збільшенням маси тіла. Дані, отримані у даному дослідженні, вказують на те, що незважаючи на компенсаторну відносну активацію антитромбіну III в обстежених відзначалася недостатність іншої найважливішої антикоагулянтної системи - протеїну C, і погіршення її функціонування було пов'язано зі збільшенням маси тіла.

Як показала інтегральна оцінка стану коагуляційної та антикоагуляційної систем крові у хворих на ЦД 2-го типу з ожирінням, ті або інші протромбогенні порушення гемостазу мали місце в абсолютної більшості пацієнтів $(94,6 \%)$, а у 64,3\% випадків вони носили поєднаний характер, тобто торкалися одразу декількох ланок плазмового гемостазу, антикоагулянтної та фібринолітичної систем.

Як маркер хронічного підгострого системного запалення, притаманний поруч із фібриногеном ЦД 2-го типу та вісцеральному ожирінню, досліджено рівень СРБ у крові. Слід зазначити, що СРБ є не лише гострофазним білком і маркером запалення, але також важливим і незалежним предиктором розвитку СС3 [8]. В обстежених виявлено вірогідне підвищення концентрації СРБ у крові порівняно з контрольною групою хворих $(4,21[2,47 ; 9,39]$ мг/л проти 0,98 $[0,69 ; 1,4] \mathrm{мг/л,} \mathrm{p}<0,001)$.

у 42,9\% впадків серед пацієнтів із ЦД 2-го типу й ожирінням відзначено підвищення концентрації СРБ понад верхню межу референсного інтервалу (>5,0 мг/л), тоді як у контрольній групі всі значення цього показника були в його межах. Встановлено вірогідну позитивну асоціацію рівня СРБ із масою тіла $(r=0,45 ; p<0,001)$, IMT $(r=0,54 ; p<0,001)$ та ОТ $(r=0,49 ; p=0,001)$, концентрацією фібриногену $(r=0,48 ; p<0,005)$ й активністю ІАП-1 ( $r=0,41 ; p<0,001)$ у плазмі крові, а також концентрацією інсуліну $(r=0,32 ; p<0,05)$ і показником інсулінорезистентності HOMA-IR $(r=0,28 ; p<0,05)$. Ці результати не лише підтверджують вже наявні дані про взаємозв'язки між запаленням, ЦД 2-го типу й ожирінням, але також вказують на поєднаний і взаємозв'язаний розвиток і посилювання прокоагулянтного та прозапального станів на тлі прогресування ожиріння та інсулінорезистентності.

У процесі роботи проведено також визначення концентрації адипонектину - єдиного протективного адипоцитокіну. Порівняно з хворми контрольної групи пацієнти з ЦД 2-го типу й ожирінням мали вірогідно нижчий рівень адипонектину $(9,74[7,25 ; 18,96]$ нг/мл проти 17,38 [10,09; 21,37] нг/мл, p<0,05); крім того, виявлено значущу позитивну асоціацію рівня адипонектину з концентрацією ХСлПВЩ у сироватці крові $(r=0,42 ; p<0,05)$, що відображає поєднане зниження цих протективних чинників за наявності інсулінорезистентності та вісцерального ожиріння.

Отже, нами проведено вивчення стану коагуляційної та антикоагуляційної систем у комплексі з рівнем маркерів запалення у пацієнтів із ЦД 2-го типу й ожирінням, показано, що ті або інші прокоагулянтні порушення мають місце в абсолютної більшості таких хворих і, як правило, носять поєднаний характер, тобто торкаються одразу декількох ланок системи гемостазу. Показано діагностичну значущість як скринінгових методів оцінки зсідання крові, так і більш поглиблених досліджень для діагностики протромбогенного стану у пацієнтів із ЦД 2-го типу й ожирінням. Показано тісний взаємозв'язок між запаленням, порушеннями гемостазу й окремими чинниками ризику розвитку ССЗ у пацієнтів із ЦД 2-го типу й ожирінням, а також продемонстровано посилення прозапального стану та прокоагулянтних зсувів на тлі прогресування ожиріння й інсулінорезистентності.

Результати проведеного дослідження вказують на необхідність скринінгового визначення параметрів коагулограми для максимально раннього виявлення прокоагулянтних порушень, а в окремих випадках (під час підготовки до планового хірургічного втручання, перед призначенням замісної гормональної терапії, за наявності додаткових чинників ризику виникнення тромбозу - спадкових коагулопатій, тромботичних захворювань в анамнезі, вад серця та 
судин, тривалої іммобілізації, катетеризації вен тощо) - дослідження системи гемостазу з визначенням активності IAП-1, FVIII, vWF і системи протеїну С у пацієнтів із ЦД 2-го типу й ожирінням. Враховуючи тісний взаємозв'язок процесів системного запалення та гіперкоагуляції за ЦД 2-го типу з ожирінням, у разі потреби повнішої оцінки серцево-судинного ризику до комплексного обстеження таких пацієнтів рекомендується включати визначення концентрацій С-реактивного білка та фібриногену.

\section{ВИСНОВКИ}

1. Прокоагулянтні порушення мають місце в абсолютної більшості пацієнтів із ЦД 2-го типу та вісцеральним ожирінням (94,6\%), у 64,3\% випадків ці порушення носять поєднаний характер, торкаючись одразу декількох ланок коагуляційної системи крові. До найчастіших порушень гемостазу належать підвищення активності ІАП-1 (87,5\%), що відображає недостатність фібринолізу; підвищення активності чинника коагуляції VIII (53,6\%), що свідчить про активацію зовнішнього каскаду зсідання крові; недостатність антикоагулянтної системи протеїну C $(23,2 \%)$.

2. Хронічне підгостре системне запалення у пацієнтів із ЦД 2-го типу та вісцеральним ожирінням проявляється вірогідним підвищенням концентрації маркерів запалення - фібриногену й С-реактивного білка, а також зниженням рівня адипонектину.

3. Вираженість прозапальних і прокоагулянтних порушень у хворих на ЦД 2-го типу з вісцеральним ожирінням асоційовано з антропометричними та біохімічними маркерами ожиріння, що вказує на поєднаний і взаємозв'язаний розвиток прокоагулянтного та прозапального станів на тлі прогресування ожиріння та інсулінорезистентності.

Перспективи подальших досліджень. Перспективним є розроблення схеми ранньої передклінічної діагностики, вдосконалення підходів до лікування прокоагулянтних і прозапальних порушень у хворих на ЦД 2-го типу з ожирінням.

\section{ЛITEPATYPA}

1. Vazzana N. Diabetes mellitus and thrombosis / N. Vazzana, P. Ranalli, C. Cuccurullo, G. Davi // Thromb. Res. - 2012. - Vol. 129, №3. - P. 371-377. 2. Alessi M.C. Plasminogen activator inhibitor-1, adi- pose tissue and insulin resistance / M.C. Alessi, M. Poggi, I. Juhan-Vague // Curr. Opin. Lipidol. 2007. - Vol. 18, №3. - P. 240-245.

3. Братусь В.В. Ожирение, инсулинорезистентность, метаболический синдром: фундаментальные и клинические аспекты / В.В. Братусь, Т.В. Талаева, В.А. Шумаков. - К.: Четверта хвиля, 2009. - 416 с.

4. Yong $W$. Remission of insulin resistance in type 2 diabetic patients after gastric bypass surgery or exenatide therapy / W. Yong, W. Shibo, L. Jingang // Obes. Surg. - 2012. - Vol. 22, №7. P. 1060-1067.

5. Undas $A$. Hyperglycemia is associated with enhanced thrombin formation, platelet activation, and fibrin clot resistance to lysis in patients with acute coronary syndrome / A. Undas, I. Wiek, E. Stepien [et al.] // Diabetes Care. - 2008. - Vol. 31, №8. - P. 1590-1595.

6. Крамарева В.Н. Уровни маркеров тромбинемии и тромбообразования у больных эссенциальной артериальной гипертензией с кардиоваскулярным риском / В.Н. Крамарева, В.Г. Гриценко, И.Н. Колесникова [и др.] // Науковий вісник Національного медичного університету імені О.О. Богомольця. - 2009. - №4. C. $177-180$.

7. Ibrahim M.M. Subcutaneous and visceral adipose tissue: structural and functional differences / M.M. Ibrahim // Obes. Rev. - 2010. - Vol. 11, №1. - P. 8-11.

8. Берковская М.А. Метаболический синдром как протромбогенное состояние / М.А. Берковская, С.А. Бутрова // Ожирение и метаболизм. - 2009. №3 (20). - C. 3-9.

\section{PЕЗЮМЕ}

\section{Показатели систем коагуляции и}

фибринолиза, маркеры воспаления у больных сахарным диабетом 2-го типа с ожирением К.Ф. Кехиопуло

В работе представлены данные изучения уровней провоспалительных маркеров и состояния систем коагуляции и фибринолиза у пацинтов с сахарным диабетом (СД) 2-го типа и висцеральным ожирением во взаимосвязи с факторами риска развития сердечно-сосудистых заболеваний. С этой целью были обследованы 56 больных. Контрольную группу составили 20 больных, соответствующих по возрасту и длительности СД 2-го типа, но без абдоминального ожирения. Прокоагулянтные нарушения выявлены у абсолютного большинства пациентов с СД 2-го типа и висцеральным ожирением (94,6\%), при этом у 64,3\% обследованных эти нарушения носили сочетанный характер с поражением нескольких звеньев свертывающей системы крови. Самыми частыми нарушениями гемостаза являются: повышение активности активатора плазминогена 1-го типа $(87,5 \%)$, что отражает недостаточность фибринолиза; повышение активности фактора коагуляции 
VIII (53,6\%), что свидетельствует об активации внешнего каскада свертывания крови; недостаточность антикоагулянтной системы протеина С $(23,2 \%)$. Хроническое подострое системное воспаление у пациентов с СД 2-го типа и висцеральним ожирением проявляется достоверным повышением концентрации маркеров воспаления - фибриногена и C-реактивного белка, а также снижением уровня адипонектина. Выраженность провоспалительных и прокоагулянтных нарушений у больных СД 2-го типа с висцеральным ожирением ассоциируется с антропометрическими и биохимическими маркерами ожирения.

Ключевые слова: сахарный диабет 2-го типа, ожирение, показатели коагуляции и фибринолиза, маркеры воспаления.

\section{SUMMARY}

Indexes of the coagulation and fibrinolytic system components, markers of inflammation in patients with type 2 diabetes mellitus and obesity

\section{K. Kehiopulo}

The author presents the data on a study of the markers of inflammation levels and state of the coagulation and fibrinolytic system components systems in patients with type 2 diabetes mellitus (DM) and visceral obesity in connection with cardiovascular diseases risk factors. With this purpose, 56 patients have been followed up. The control group included 20 patients хворих corresponding on age and durations of type $2 \mathrm{DM}$ but without abdominal obesity. It has been shown that procoagulant changes are marked at absolute majority of type 2 DM patients with visceral obesity (94.6\%), in $64.3 \%$ patients these changes were connected with the defeat of a few links of the coagulation blood system. The most frequent changes of hemostasis is an increase of activity of plasminogen activator inhibitor 1 (87.5\%), that represents insufficiency of fibrinolysis; increase of activity of coagulation factor VIII (53.6\%) and testifies to activating of external cascade of hemopexis, and insufficiency of the anticoagulating system of protein C (23.2\%). Chronic subacute system inflammation in type 2 DM patients with visceral obesity shows up the reliable increase of concentration of markers of inflammation - fibrinogen and C-reactive protein, and also by the decline of adiponectin level. Expressed of proinflammatory and procoagulanting changes in patients with type $2 \mathrm{DM}$ and visceral obesity associated with the anthropometric and biochemical markers of obesity.

Key words: type 2 diabetes mellitus, obesity, coagulation and fibrinolytic system components, markers of inflammation. 